\title{
Auxotypes, plasmid contents, and serovars of gonococcal strains (PPNG and non-PPNG) from Jamaica
}

\author{
J R DILlON,* M CARBALlo,* S D KING, $†$ A R BRATHWAITE $\ddagger$
}

From the *Antimicrobials and Molecular Biology Division, Laboratory Centre for Disease Control, Ottawa, Canada; †Department of Microbiology, University of the West Indies; and the $\ddagger$ Comprehensive Health Centre, Kingston, Jamaica, West Indies

SUMMARY The analysis of the auxotypes and plasmid profiles of 459 non-PPNG strains from Jamaica suggests that strains have been imported to the island. Unlike in many developing countries where strains are differentiated by only a few auxotypes, 13 different auxotypes were identified in the non-PPNG strains. In Jamaica over $10 \%$ of the strains were plasmid free and required proline, citrulline, and uracil $\left(\mathrm{PCU}^{-}\right)$for growth. These isolates predominate in Canada and are increasingly reported from areas of the United States of America and Europe. The serological analysis of 168 of the non-PPNG strains indicated that most $(76 \%, 128)$ were from serogroup WII/III. Serogroup WII/III strains comprised 17 serovar combinations with GS and $\mathrm{Ph}$ reagents, whereas serogroup WI strains included only four serovars. Unusually, most WI Aedgkih non-PPNG strains were wild type or proline requiring. Strains of serovar Aedg were especially noted (in 93\%, 13/14) for carriage of the transfer plasmid. The first 20 PPNG strains isolated in Jamaica proved to have multiple origins as they had eight variations of auxotype, serovar, and plasmid content. Most $(60 \%, 12 / 20)$ of those isolated were typed as serogroup WI, and 10 of these isolates were serovar Aedgkih. Although most $(70 \%, 14 / 20)$ PPNG strains harboured African type plasmids with or without transfer plasmids, six also carried Asian type plasmids (with the transfer plasmid).

Gonococcal isolates are differentiated for epidemiological purposes using a combination of techniques. These include assessing nutritional growth requirements (or auxotype), ${ }^{1-3}$ analysing plasmid content, ${ }^{4-6}$ and characterising strains by serological methods using monoclonal reagents. ${ }^{7-9}$ Characterising strains using such methods has facilitated gathering data about the dissemination of both penicillinase producing Neisseria gonorrhoeae (PPNG) and non-PPNG strains. ${ }^{10-13}$ Relations between the variables serovar, plasmid content, and auxotype are also specific for certain geographical areas and are correlated with other variables, such as susceptibility to antimicrobials and expression of disease. ${ }^{14-17}$ Although analyses of the above variables

Address for reprints: Dr J R Dillon, Antimicrobials and Molecular Biology Division, Laboratory Centre for Disease Control, Tunney's Pasture, Ottawa, Canada K1A OL2.

Accepted for publication 11 November 1986 have often been reported from areas in north America, parts of Europe, and certain regions of Africa and Asia, virtually no molecular epidemiological data have been compiled on gonococcal infections in Latin America and Caribbean countries. ${ }^{1819}$ The present study was undertaken to characterise Jamaican PPNG and non-PPNG strains by auxotype, plasmid content, and serovar to develop a data base for future comparisons and to ascertain, if possible, the origin of certain strains. This study was completed in conjunction with a clinical and microbiological study that compared two regimens for treating acute uncomplicated gonorrhoea and that correlated treatment failure with in vitro susceptibility to antimicrobials. ${ }^{20}$

\section{Materials and methods}

All isolates were collected during a study undertaken in 1983-4 to compare the efficacy of two regimens in treating acute uncomplicated gonorrhoea, to assess 
the MICs of eight antimicrobial agents for gonococcal isolates, and to correlate in vitro results with the efficacy of treatment. ${ }^{20}$ The results of that study are published elsewhere. ${ }^{20}$ The isolates were identified as $N$ gonorrhoeae as described previously. ${ }^{20}$ Isolates were forwarded to Ottawa from Jamaica for their identity to be confirmed and for molecular biological, serological, and genetic characterisation. We initially identified $\beta$ lactamase producing isolates by the chromogenic cephalosporin method. ${ }^{21}$

We characterised 459 non-PPNG isolates and 20 PPNG isolates by nutritional growth requirement and plasmid content. We assessed nutritional growth requirements (auxotype) using the method of Hendry and Stewart ${ }^{22}$ as modified by Hendry. ${ }^{23}$ Plasmid content was analysed using the method published by $\mathrm{Di}$ llon et al. ${ }^{5}$ Control strains for plasmid content analysis and auxotyping have been described previously. ${ }^{5}$

Serological characterisation of 168 non-PPNG strains and 20 PPNG strains by coagglutination using monoclonal antibodies to protein I was performed using methods described by Tam et $a l^{9}$ and Bygdeman et al. $^{24}$ Two panels of monoclonal reagents were used, the GS and $\mathrm{Ph}$ reagents. ${ }^{25}$ The designation of specific serovars has been described previously. ${ }^{25} 26$ Serological reagents and control strains were purchased from Dr S Bygdeman, the STD Research Group, Huddinge University Hospital, Huddinge, Sweden.

\section{Results}

We characterised 459 non-PPNG strains by nutritional requirement and plasmid content (table 1); 13 different auxotypes were observed. Most (54\%) of the

Table 1 Auxotype and plasmid content of 459 non-penicillinase-producing strains of Neisseria gonorrhoeae from Jamaica

\begin{tabular}{lcccc}
\hline \multicolumn{5}{c}{ Plasmid content (megadaltons) } \\
\cline { 2 - 5 } Auxotype $^{*}$ & $2 \cdot 6$ & $2 \cdot 6+24 \cdot 5$ & No plasmids & Total (\%) \\
\hline NR & 159 & 87 & 3 & $249(54 \cdot 2)$ \\
Pro $^{-}$ & 86 & 29 & 0 & $115(25 \cdot 1)$ \\
PCU $^{-}$ & 0 & 0 & 50 & $50(10 \cdot 9)$ \\
Orn & 8 & 10 & 0 & $18(3 \cdot 9)$ \\
Other & $16 \dagger$ & $6 \ddagger$ & $5 \S$ & $27(5 \cdot 9)$ \\
Total & 269 & 132 & 58 & 459 \\
\hline
\end{tabular}

${ }^{*} \mathrm{NR}=$ non-requiring or wild type; $\mathrm{P}^{-}$or $\mathrm{Pro}^{-}=$proline requiring; $\mathrm{C}^{-}=$citrulline requiring; $\mathrm{U}=$ uracil requiring; $\mathrm{O}^{-}$or $\mathrm{Orn}^{-}=$ ornithine requiring; $\mathbf{H}=$ hypoxanthine requiring; $\mathbf{M}=$ methionine requiring.

†Included $\mathrm{OUH}^{-}$(4), $\mathrm{PCUH}^{-}$(4), $\mathrm{H}^{-}$(2), $\mathrm{POUH}^{-}$(2), and one

each of $\mathrm{PO}^{-}, \mathrm{OH}^{-}, \mathrm{M}^{-}$, and $\mathrm{C}^{-}$auxotypes.

†Included $\mathrm{OUH}^{-}(2)$, and one each of $\mathrm{PO}^{-}, \mathrm{OH}^{-}, \mathrm{PH}^{-}$, and

$\mathrm{C}^{-}$auxotypes.

§Included $\mathrm{PCUH}^{-}$(4) and $\mathrm{OUH}^{-}$(1) auxotypes. isolates were wild type (non-requiring); $25 \%$ required proline for growth, $11 \%$ required proline, citrulline, and uracil $\left(\mathrm{PCU}^{-}\right)$; and the remaining $10 \%$ comprised the 10 other auxotypes. Although 59\% $(269 / 459)$ of the isolates harboured the cryptic (2.6 megadalton) plasmid, the 24.5 megadalton transfer plasmid was isolated from $29 \%(132 / 459)$ of the strains. In addition, $13 \%(58 / 459)$ of the strains were plasmid free. Most $(50,86 \%)$ of the 58 plasmid free strains were of the $\mathrm{PCU}^{-}$auxotype.

The serovars of 168 non-PPNG isolates were identified using both the GS and Ph monoclonal typing reagents (table 2). ${ }^{23}$ Most strains (127/168, $75.6 \%$ ) were of serogroup WII/III. Four serovars comprised serogroup WI isolates; serovar Aedgkih comprised $46 \%$ (19/41) followed by serovar Aedg $(34 \%, 14)$. The serogroup WII/III isolates were differentiated into 12 serovars with the GS reagents and 17 serovar combinations when the $\mathrm{Ph}$ monoclonal reagents were added; the addition of the $\mathrm{Ph}$ panel of reagents did not increase the resolution of WI serogroups. With serogroup WII/III isolates, serovar Bacjk strains predominated $(32 \%, 41 / 127)$, followed by serovar Bacegjk (19\%, 24), serovar Bajk $(17 \%, 21)$, and serovar Bacejk $(16 \%, 20)$ strains. Thus $84 \%$ of the serogroup WII/III strains included only four serovars.

The analysis of the relation between serogroup and auxotype for non-PPNG isolates (table 2) indicated that most $(19 / 41,46 \%)$ of the serogroup WI comprised wild type strains. Although strains of serovar Aedgkih included several auxotypes, all the proline requiring strains and four out of five of the $\mathrm{OUH}^{-}$ strains were serovar Aedgkih. Of the WII/III serogroup strains, $60 \%(24 / 40)$ of those with proline requiring auxotypes were of serovar Bacjk. The $\mathrm{PCU}^{-}$ strains comprised two serovar combinations, Bacejk/Brpyust and Bacegjk/Brpyust.

Plasmid free strains comprised both WI (two strains) and WII/III serovars (32 strains). The WII/III plasmid free strains were related and included two serovars, Bacejk and Bacegjk, which differed by only one epitope. Strains harbouring the cryptic 2.6 megadalton plasmid alone included all four WI serovars and nine WII/III serovars. Almost half $(48 \%, 37)$ of the 77 serogroup WII/III strains harbouring the cryptic plasmid alone were of serovar Bacjk. Similarily, several strains from all WI serovars harboured both cryptic and transfer plasmids; however, 72\% (13/18) of these isolates were serovar Aedg.

Table 3 summarises the auxotypes, serovars, and plasmid contents of the first PPNG strains isolated in Jamaica. The 20 strains characterised comprised three auxotypes, most $(80 \%, 16)$ being wild type (nonrequiring), $15 \%$ (three) requiring proline (pro ${ }^{-}$) for growth, and the remaining isolate requiring proline 
Auxotype, plasmid content, and serovars of gonococcal strains (PPNG and non-PPNG) from Jamaica

ble 2 Relation between serovar, auxotype, and plasmid content of 168 non-penicillinase-producing strains of Neisseria gonorrhoeae

\begin{tabular}{|c|c|c|c|c|c|c|c|c|c|c|c|}
\hline \multirow[b]{2}{*}{ ogroup } & \multicolumn{2}{|l|}{ Serovar } & \multirow[b]{2}{*}{ No } & \multicolumn{5}{|c|}{ Auxotype } & \multicolumn{3}{|c|}{$\begin{array}{l}\text { Plasmid content } \\
\text { (megadaltons) }\end{array}$} \\
\hline & $\begin{array}{l}G S \\
\text { reagents }\end{array}$ & $\begin{array}{l}\text { Ph } \\
\text { reagents }\end{array}$ & & $N R$ & Pro $^{-}$ & $P C U^{-}$ & $\mathrm{Orn}^{-}$ & Othert & $2 \cdot 6$ & $\begin{array}{l}2 \cdot 6+ \\
24 \cdot 5\end{array}$ & None \\
\hline & $\begin{array}{l}\text { Aedgkih } \\
\text { Aedg } \\
\text { Aedih } \\
\text { Aed }\end{array}$ & $\begin{array}{l}\text { Arost } \\
\text { Arot } \\
\text { Arst } \\
\text { Art }\end{array}$ & $\begin{array}{r}19 \\
14 \\
5 \\
3\end{array}$ & $\begin{array}{l}5 \\
8 \\
5 \\
1\end{array}$ & 9 & & $\begin{array}{l}5 \\
1\end{array}$ & $\begin{array}{l}5 \\
1 \\
1\end{array}$ & $\begin{array}{r}16 \\
1 \\
3 \\
1\end{array}$ & $\begin{array}{r}3 \\
13 \\
1 \\
1\end{array}$ & $\begin{array}{l}1 \\
1\end{array}$ \\
\hline tal & & & 41 & 19 & 9 & & 6 & 7 & 21 & 18 & 2 \\
\hline I/III & $\begin{array}{l}\text { Bacjk } \\
\text { Bajk } \\
\text { Bacejk } \\
\text { Bacegjk } \\
\text { Bacgjk } \\
\text { Other } \ddagger\end{array}$ & $\begin{array}{l}\text { Bropt (38), } \\
\text { Bropyt (1), } \\
\text { Bropst (2) } \\
\text { Bropt } \\
\text { Brpyust (19), } \\
\text { Broput (1) } \\
\text { Brpyust } \\
\text { Bropt }\end{array}$ & $\begin{array}{r}41 \\
21 \\
\\
20 \\
24 \\
6 \\
15\end{array}$ & $\begin{array}{r}14 \\
7 \\
4 \\
2 \\
5 \\
13\end{array}$ & $\begin{array}{c}24 \\
10 \\
4 \\
1 \\
1\end{array}$ & $\begin{array}{l}11 \\
19\end{array}$ & $\begin{array}{l}1 \\
4 \\
1 \\
1\end{array}$ & $\begin{array}{l}2 \\
1\end{array}$ & $\begin{array}{c}37 \\
19 \\
7 \\
\\
6 \\
8\end{array}$ & $\begin{array}{l}2 \\
3 \\
7\end{array}$ & $\begin{array}{l}11 \\
21\end{array}$ \\
\hline tal & & & 127 & 45 & 40 & 30 & 7 & 5 & 77 & 18 & 32 \\
\hline
\end{tabular}

uxotype designations as for table 1 .

I serovars OUH ${ }^{-}(5)$ and $\mathrm{OH}^{-}(2) ; \mathrm{WII} / \mathrm{III}$ serovars $\mathrm{H}^{-}$(1), $\mathrm{M}^{-}$(1), $\mathrm{POUH}^{-}$(1), and PCUH ${ }^{-}$(2).

ik/Brpyt, Bropyst, Bopyt (4), Bacgjk/Bropt (4), Baejk/Broput (2), Bejk/Broput (2), Bcgk/Bopyst (1), Bghk/Bopyvt (1), and Beghjk/Bpyvut (1).

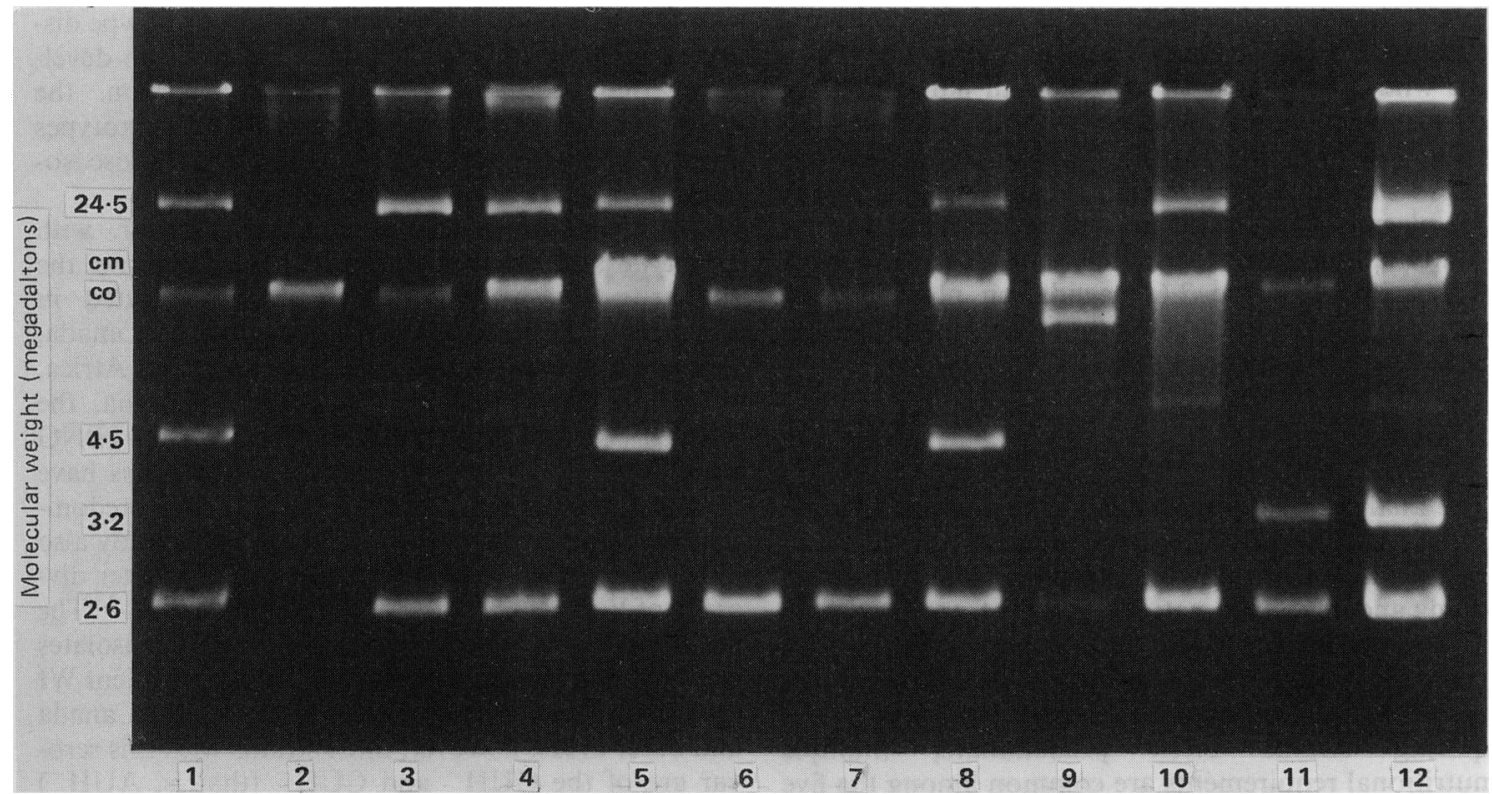

Figure Typical plasmid DNA profiles on $1 \%$ agarose gel electrophoresis. Lane $1=$ control strain GC1-182 $(2 \cdot 6,4 \cdot 5$, and 24.5 megadalton plasmids); lane 2 =plasmid free strain; lanes 3,4 , and $10=$ strains with 2.6 and 24.5 megadalton plasmids; lanes 5 and $8=$ strains with $2 \cdot 6,4 \cdot 5$, and $24 \cdot 5$ megadalton plasmids; lanes 6 and $7=$ strains with $2 \cdot 6$ megadalton plasmid; lane $11=$ strain with 2.6 and 3.2 megadalton plasmids; lane $9=2.6$ megadalton plasmid and concatenate; lane $12=$ control strain GC 1-159, $(2 \cdot 6,3 \cdot 2$, and $24 \cdot 5$ megadalton plasmids $) ;(\mathrm{cm}=$ chromosomal; $c o=$ concatenate. $)$ 
Table 3 Relation between serovar, auxotype, and plasmid content of 20 penicillinase-producing strains of Neisseria gonorrhoeae

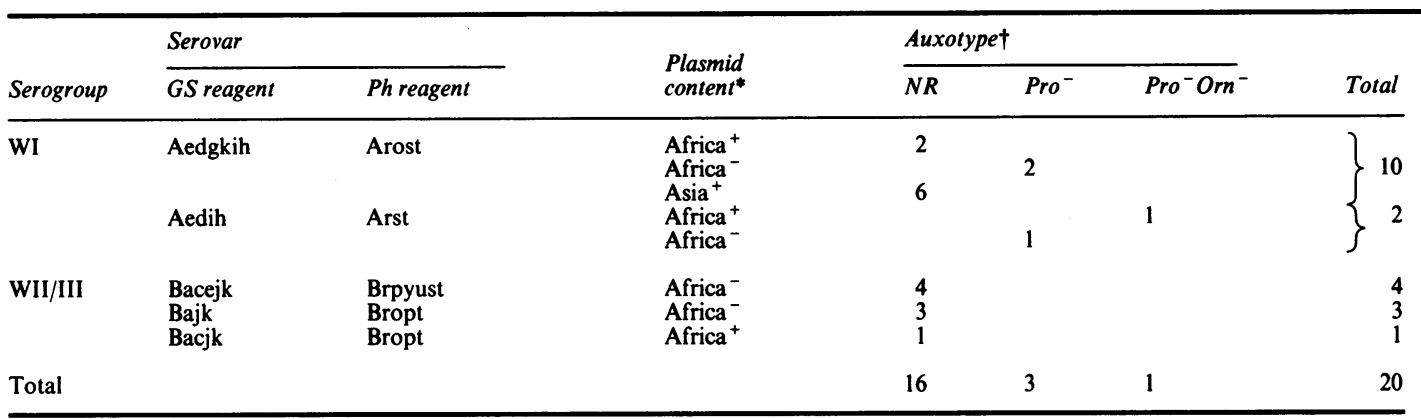

${ }^{*}$ Africa ${ }^{+}, 2 \cdot 6,3 \cdot 2$, and $24 \cdot 5$ megadalton plasmids; Africa $^{-}, 2 \cdot 6$ and $3 \cdot 2$ megadalton plasmids; Asia $^{+}, 2 \cdot 6,4 \cdot 5$, and $24 \cdot 5$ megadalton plasmids. †Auxotype designations as for table 1 .

and ornithine for growth (pro- $\left.{ }^{-}{ }^{-}\right)$. African type or Asian type penicillinase producing plasmids were identified in the strains. All six strains with Asian type plasmids also harboured a transfer plasmid (Asia ${ }^{+}$) whereas only four of 14 strains with African type plasmids also carried the transfer plasmid $\left(\mathrm{Afr}^{+}\right)$. Strains of the Asia ${ }^{+}$type were of one auxotype (wild type) and one serovar (Aedgkih/Arost), and could therefore be considered to be related. Most (12/20) of the PPNG strains were serogroup WI, and 10 of these strains were of serovar Aedgkih. Strains with this serovar comprised two auxotypes and three plasmid types. All PPNG strains with WII/III serovars were of the wild type auxotype, and they all harboured the Africa type plasmid with or without transfer plasmids. The plasmid content of typical gonococcal isolates from Jamaica is depicted in the figure, in which the plasmid free strains as well as all other plasmid combinations recorded in this study are visualised. Concatemers of the 2.6 megadalton plasmid were verified by hybridisation to cryptic plasmid probes labelled with ${ }^{32} \mathbf{P}$ (data not shown).

\section{Discussion}

The analysis of the molecular epidemiology of both PPNG and non-PPNG strains has uncovered interesting differences between strains isolated in developing and developed nations. Strains from areas such as Canada, the United States of America, and Europe generally comprise several different auxotypes. $^{132227}$ Although wild type and proline requiring strains often predominate, multiple nutritional requirements are common among the five most predominant auxtotypes. ${ }^{1327}$ For example, the $\mathrm{PCU}^{-}$auxotype is the most prevalent auxotype in Canada, comprising almost $40 \%$ of strains surveyed in 1981-3 (Dillon, unpublished data). In 1973 these strains made up less than $2 \%$ of all gonococcal isolates in Canada and were not reported in other ar- eas. ${ }^{27}$ Although they are being recovered more often from areas of Europe and the United States, $\mathrm{PCU}^{-}$ strains have not been detected in many countries of the developing world. ${ }^{27} 32$ On the other hand, strains from developing countries, as recently reported from Chile, Korea, areas of West Africa, and Gabon, ${ }^{11} 122832$ generally comprise only a few auxotypes. Wild type and proline requiring strains predominate in these countries, followed distantly by strains requiring arginine, arginine and proline, or methionine. Thus the array of auxotypes observed in non-PPNG strains in Jamaica places its auxotype distribution more in line with those observed in developed than developing nations. In addition, the observance of an $11 \%$ incidence of $\mathrm{PCU}^{-}$auxotypes further distinguishes Jamaican strains from those isolated in other developing countries.

The comparison of gonococcal serovar with auxotype and plasmid content further confirms the similarity of the non-PPNG strains isolated in Jamaica to those from North America. In Canada, regions of Europe, specific areas of Asia and Africa, the United States of America, and Australia, the WII/III serogroup predominates in non-PPNG isolates. ${ }^{121533-35}$ By contrast, other workers have characterised strains from Africa as being predominantly WI and wild type. ${ }^{1233}$ The present study also reflects previous observations showing a greater diversity of WII/III serovars than WI serovars. ${ }^{33-35}$ The most prevalent WI serovar in the Jamaican isolates was Aedgkih. This is similar to the most prevalent WI serovar in Canada and other areas. ${ }^{932} 33$ In Canada and other areas, however, most strains with this serovar are of the $\mathrm{OUH}^{-}$and $\mathrm{CUH}^{-}$(that is, $\mathrm{AUH}^{-}$) auxotypes. ${ }^{1532-3436}$ By contrast, most of the isolates from Jamaica with this serovar were wild type or proline requiring. Isolates requiring proline, citrulline, and uracil $\left(\mathrm{PCU}^{-}\right)$have been found to comprise only a few serovars, the predominant serovar being Bacejk (PrIB-2 using the Knapp nomenclature). ${ }^{1526293234}$ 
$\mathrm{PCU}^{-}$strains with serovars that differ by one epitope have also been noted. ${ }^{15293234}$ In the present study, $\mathrm{PCU}^{-}$strains of serovar Bacegjk have not been reported previously, but are obviously related to $\mathrm{PCU}^{-}$ strains of the serovar Bacejk characterising these strains in other areas.

The variety of combinations of serovar, auxotype, and plasmid content in PPNG strains in Jamaica attests to the importation of isolates rather than the epidemic spread of a single imported strain. In the latter case only a single combination of auxotype, serovar, and plasmid content would be recovered, as was the case in Santiago, $\mathrm{Chile}^{\mathbf{2 8}}$ and in outbreaks in the United States of America and Canada. ${ }^{35} 37$ Ten of the 20 PPNG strains isolated during the study were typed as serovar Aedgkih and were of wild type or proline requiring auxotypes. PPNG strains with these combinations of serovar and auxotype have been noted in west African isolates. ${ }^{3338}$ This serovar has also been noted in PPNG strains in southern Florida. ${ }^{32}$ All WII/III PPNG strains harboured African type plasmids; PPNG strains with these WII/III serovars have been thought to originate in Asia and generally harbour Asian type plasmids. ${ }^{32} 3338$ As the WII/III serovars of the Jamaican PPNG strains were also prevalent among non-PPNG strains, the African type plasmid may possibly have been transferred by conjugation from a WI PPNG strain to the most prevalent serogroup WII/III local strains. Six of the isolates that were wild type and serovar Aedgkih had the same plasmid content (Asia ${ }^{+}$), which indicated a connection between patients with these isolates.

The three most prevalent WII/III serovars in both non-PPNG and PPNG strains were also the most prevalent in a recent Canadian study and globally. ${ }^{334}$ Although a recent Canadian study has shown a positive correlation between serogroup WII/III strains and carriage of the transfer plasmid in non-PPNG isolates, ${ }^{34}$ the present study indicates that an equal number of strains from each serogroup harboured the transfer plasmid. Serovar Aedg strains were especially notable for their carriage of the transfer plasmid.

In summary, the present study shows that the molecular epidemiology of gonococcal strains in Jamaica, unlike many developing countries, reflects the distribution of gonococcal strains of developed countries, particularly its northern neighbours, Canada and the United States of America. ${ }^{32}{ }^{34}$ The importation of strains, probably by tourists, is reflected in the diverse serological, nutritional, and molecular characteristics of the isolates.

This work was supported in part by a grant (No 3-P-81-0240), to S D King from the International Development Research Centre, Ottawa, Canada.
References

1 Catlin BW. Nutritional profiles of Neisseria gonorrhoeae, Neisseria meningitidis and Neisseria lactamica in chemically defined media and the use of growth requirements for gonococcal typing. J Infect Dis 1973;128:178-94.

2 Hendry AT, Stewart IO. Auxanographic grouping and typing of Neisseria gonorrhoeae. Can J Microbiol 1979;25:512-21.

3 Ansink-Schipper MC. Auxanographic typing of Neisseria gonorrhoeae isolated in the Netherlands. Amsterdam, the Netherlands: University of Amsterdam, 1985. PhD Thesis.

4 Riou JY, Courvalin P. Neisseria gonorrhoeae plasmids: theoretical study and practical consequences. WHO/VDT/ RES/GON 85 1985;146:24.

5 Dillon JR, Pauzé M, Yeung K-H. Molecular and epidemiological analysis of penicillnase producing strains of Neisseria gonorrhoeae isolated in Canada 1976-84: evaluation of new auxotypes and $\beta$ lactamase encoding plasmid. Genitourin Med 1986;62:151-7.

6 Roberts M, Piot P, Falkow S. The ecology of gonococcal plasmids. J Gen Microbiol 1979;114:491-4.

7 Sandström E, Danielsson D. Serology of Neisseria gonorrhoeae. Classification with co-agglutination. Acta Pathol Microbiol Scand $[B]$ 1980;88:27-38.

8 Knapp JS, Tam MR, Nowinski RC, Holmes KK, Sandström EG. Serological classification of Neisseria gonorrhoeae with use of monoclonal antibodies to gonococcal outer membrane protein 1. J Infect Dis 1984;150:44-8.

9 Tam MR, Buchanan TM, Sandström EG, et al. Serological classification of Neisseria gonorrhoeae with monoclonal antibodies. Infect Immun 1982;36:1042-53.

10 Yeung K-H, Dillon JR, Pauzé M, Wallace E. Outbreak of PPNG caused by a novel 3.05 Md penicillinase-producing plasmid (Toronto-type) related to the Asian-type plasmid. J Infect Dis 1986;153:1162-5.

11 Yvert F, Frost E, Guibourdenche M, Riou JY, Ivanoff B. Auxotypes and serogroups of penicillinase producing and nonproducing strains of Neisseria gonorrhoeae isolated in Franceville, Gabon. Genitourin Med 1985;61:99-102.

12 Odugbemi TO, Brown ST, Biddle J, et al. Plasmid profile, serogrouping, and auxotyping of Neisseria gonorrhoeae isolates from Africa. British Journal of Venereal Diseases 1983;59:41-3.

13 Bygdeman S, Kallings I, Danielsson D. Serogrouping and auxotyping for epidemiological study of beta-lactamase-producing Neisseria gonorrhoeae strains isolated in Sweden. Acta Derm Venereal (Stockh) 1981;61:329-34.

14 Dillon JR, Pauzé M. Relationship between plasmid content and auxotype in Neisseria gonorrhoeae isolates. Infect Immun 1981; 33:625-8.

15 Brunham RC, Plummer F, Slaney L, Rand F, DeWitt W. Correlation of auxotype and protein I type with expression of disease due to Neisseria gonorrhoeae. J Infect Dis 1985;152: 339-43.

16 Stewart IO, Hendry AT. Association between the auxogroup of Neisseria gonorrhoeae and the minimum inhibitory concentration of penicillin. Sex Transm Dis 1978;6:247-52.

17 Klingeren van B, Ansink-Schipper MC, Dessens-Kroon M, Verheuvel M. Relationship between auxotype, plasmid pattern and susceptibility to antibiotics in penicillinase-producing Neisseria gonorrhoeae. J Antimicrob Chemother 1985;16:143-7.

18 Barnes RC, Holmes KK. Epidemiology of gonorrhoea: current perspectives. Epidemiol Rev 1984;6:1-30.

19 Communicable Disease Control, Pan American Health Organisation. Sexually transmitted diseases. Epidemiological Bulletin 1981;2:1-4.

20 King SD, Brathwaite AR, MacFarland D, Dillon JR. Antimicrobial sensitivity and treatment of PPNG and non-PPNG in Jamaica. Genitourin Med (in press).

21 O'Callaghan $\mathbf{C H}$, Morris A, Kirby SM, Shingler AH. Novel method for detection of $\beta$-lactamase by using chromogenic 
cephalosporin substrate. Antimicrob Agents Chemother 1972; 1:283-8.

22 Hendry AT, Stewart IO. Auxanographic grouping and typing of Neisseria gonorrhoeae. Can J Microbiol 1979;25:512-21.

23 Hendry AT. Growth responses of Neisseria gonorrhoeae auxotypes to required amino acids and bases in liquid medium. Can J Microbiol 1983;29:1309-13.

24 Bygdeman S, Danielsson D, Sandström E. Gonococcal W serogroups in. Scandinavia. A study with polyclonal and monoclonal antibodies. Acta Pathol Microbiol Scand $[B]$ 1983;91:239-305.

25 Bygdeman SM, Gillenius EC, Sandström EG. Comparison of two different sets of monoclonal antibodies for the serological classification of Neisseria gonorrhoeae. In: Schoolnik GK, Brooks G, Falkow JS, et al, eds. The pathogenic neisseriae. Washington, DC: American Society for Microbiology, 1985:31-6.

26 Knapp JS, Bygdeman S, Sandström E, Holmes KK. Nomenclature for the serological classification of Neisseria gonorrhoeae. In: Schooinik GK, Brooks G, Falkow JS, et al, eds. The pathogenic neisseriae. Washington, DC: American Society for Microbiology, 1985:4-5.

27 Dillon JR, Pauzé M. Resistance to antimicrobial agents. What next for Neisseria gonorrhoeae? Sex. Transm Dis 1984;11 suppl:353-9.

28 Moreno JG, Dillon JR, Arroyave R, et al. Identification of penicillinase producing Neisseria gonorrhoeae in Chile during clinical and microbiological study of gonococcal susceptibility to antimicrobial agents. Genitourin Med 1987;63:6-12.

29 Kohl PK, Knapp JS, Hofmann H, et al. Epidemiological analysis of Neisseria gonorrhoeae in the Federal Republic of Germany by auxotyping and serological classification using monoclonal antibodies. Genitourin Med 1986;62:145-50.

30 Noble RC, Parekh MC. Changes in the prevalence of auxotypes of Neisseria gonorrhoeae among black and white patients at- tending a clinic for sexually transmitted diseases. Sex Transm Dis 1983;10:14-7.

31 Danielsson D, Bygdeman S, Kallings I. Epidemiology of gonorrhoea: serogroup, antibiotic susceptibility and auxotype patterns of consecutive gonococcal isolates from ten different areas of Sweden. Scand J Infect Dis 1983;15:33-42.

32 Whittington WL, Vernon A, Biddle JW, et al. Serological classification of Neisseria gonorrhoeae: uses at the community level. In: Schoolnik GK, Brooks G, Falkow JS, et al, eds. The pathogenic neisseriae. Washington, DC: American Society for Microbiology, 1985:20-5.

33 Bygdeman SM. Polyclonal and monoclonal antibodies applied to the epidemiology of gonococcal infection. In: Young $\mathbf{H}$, McMillan A, eds. Immunological diagnosis of sexually transmissible diseases. New York: Marcel Decker, 1987:117-65.

34 Dillon JR, Bygdeman SM, Sandström EG. Serological ecology of Neisseria gonorrhoeae (PPNG and non-PPNG) strains: Canadian perspective. Genitourin Med 1987;63:180-8.

35 Handsfield HH, Sandström EG, Knapp JS, et al. Epidemiology of penicillinase-producing Neisseria gonorrhoeae infections. Analysis by auxotyping and serogrouping. $N$ Engl J Med 1982; 306:950-4.

36 Knapp JS, Mulko MH, Lind I, Short HB, Clark VL. Evolution of gonococcal populations in Copenhagen, Denmark, 1928-1979. In: Schoolnik GK, Brooks G, Falkow JS, et al, eds. The pathogenic neisseriae. Washington, DC. American Society for Microbiology, 1985:82-8.

37 Dillon JR, Pauzé M, Gould R, Sutherland R, Romanowski B. Penicillinase-producing Neisseria gonorrhoeae with pro- ${ }^{-}{ }^{-}{ }^{-}$, WI, Asia ${ }^{+}$phenotype. Lancet 1986;i:103-4.

38 Plummer FA, D'Costa LJ, Nsanze H, et al. Development of endemic penicillinase-producing Neisseria gonorrhoeae in Kenya. In: Schoolnik GK, Brooks G, Falkow JS, et al, eds. The pathogenic neisseriae. Washington, DC. American Society for Microbiology, 1985:101-7. 